\title{
Новое видение
}

внешнеполитического

процесса в

учебно-аналитической

литературе

М.А. Небольсина

Алексеева Т.А., Казанчев А.А. Внешнеполитический прочесс. Сравнительный анализ: Учебное пособие для вузов. М.: Аспект Пресс, 2012.

$\mathrm{Y}$ чебное пособие Алексеевой Т.А. и Казанцева А.А. «Внешнеполитический процесс. Сравнительный анализ: Учебное пособие для студентов вузов» представляет собой сравнительный анализ различных внешнеполитических решений на основе сочетания теоретических знаний и практических политических примеров.

Изменение мирополитических процессов в современную эпоху в связи с появлением новых акторов влияния - сетевых структур, непризнанных государств, негосударственных участников и т.д. - требует переосмысления категориальнопонятийного аппарата и некоторых инструментов анализа внешнеполитических процессов. Впервые в отечественной учебной литературе появилось исследование, которое строится с учетом всех аспектов внешнеполитического процесса, как формальных, так и неформальных. При этом большое внимание авторы уделяют именно неформальным, а также культурно-цивилизационным аспектам внешнеполитического процесса.

Авторам удалось провести комплексный анализ трансформации теорий международных отношений под влиянием неформальных аспектов. Параметры, которые раньше нередко считались «субъективными» и культурно релятивными, в данном исследовании рассматриваются как одни из наиболее значимых, наравне с общепризнанными аспектами внешнеполитического процесса.

Несомненным достоинством работы является то, что она хорошо структурирована. Учебник изобилует примерами, описывающими опыт различных государств, при этом обзор по государствам представлен не как простое разделение на «западную» и «восточную» модели или по цивилизационным основаниям, а с точки зрения смешанных оснований классификации. Для более глубокого понимания внешнеполитического процесса в разных государствах авторы используют сочетание различных матриц анализа:

- во-первых, речь идет о внутриполитическом уровне, который включает в себя как системные факторы - законы, аппарат государственного управления, властные отношения между различными участниками внутриполитического процесса, так и неформальные категории: различные агенты влияния, традиционные модели политического поведения, СМИ, гражданское общество, культурно-цивилизационные аспекты;

- во-вторых, авторами проводится анализ международного уровня, где государства вступают в политическое взаимодействие на двух- и многосторонней основе;

- в-третьих, авторы предлагают учитывать индивидуальный уровень, где важную роль во внешнеполитическом процессе играет глава государства, который опирается не только на системные факторы, но и на персональные социальные сети и пр.;

- в-четвертых, в работе исследуется роль политических теорий, распространенных среди различных участников, влияющих на внешнеполитический процесс;

Небольсина Мария Александровна - научный сотрудник ЦЕАБ ИМИ МГИМО(У) МИД России. E-mail:vestnik@mgimo.ru 
- в-пятых, авторы типологизируют государства с точки зрения формальных и неформальных аспектов политического устройства, что также является важной составляющей внешнеполитического процесса.

В совокупности все эти аспекты моделируют контекст, в котором протекает внешнеполитический процесс.

Авторам удалось раскрыть сложные процессы внешнеполитического дискурса с помощью простых и понятных примеров. Не перегружая учащихся информацией и фактами, авторы, с одной стороны, сумели рассказать относительно просто о весьма сложном, а с другой - оставили читателям возможность самим поразмышлять над внешнеполитическими процессами. Таким образом, данное исследование выполняет не только академические задачи и формирует у участников учебного процесса базовые навыки грамотного использования политологического категориально-понятийного аппарата, но и пробуждает интерес к познанию внешнеполитических процессов на более высоком, аналитическом уровне.

Внимание к деталям и особенностям внешнеполитического процесса в различных политических системах делает учебное пособие описательным и наглядным. Помимо анализа процесса принятия внешнеполитических решений, авторы рассматривают специфические особенности, характерные для той или иной политической системы, что формирует целостную картину у читателя. Например, авторы выделяют среди особенностей политической культуры Великобритании относительную однородность общественного мнения в стране по сравнению с континентальными государствами Европы. «Степень гласности и прозрачности в принятии решений, роль их публичных обоснований очень высока. Большую роль в обсуждении всех внешнеполитических вопросов играют ученые и эксперты», - пишут авторы.

Интересно и многомерно анализируют авторы политическую систему ФРГ, которая характеризуется высокой степенью консолидации всех ключевых политических сил, как право-, так и левоцентристских, что частично объясняется стремлением не допустить повторения диктатуры и прихода к власти нацистов или коммунистов. На большом количестве факторов авторы анализируют внешнеполитический процесс в Сингапуре, который характеризуется авторами, вслед за Ф. Закарией, как «нелиберальная демократия». Будучи исторически военно-морской базой Великобритании, а также являясь крупнейшим торговым портом в Юго-Восточной Азии, Сингапур в своей внешнеполитической деятельности в значительной степени опирается на экономические интересы. Это подтверждается активной ролью Сингапура в таком интеграционном образовании, как АСЕАН. Структурированно дан обзор внешнеполитического процесса в ряде азиатских демократических систем: рассмотрено становление демократической модели развития в Ин- дии и отражение демократических принципов во внешней политике этого государства, а также этапы эволюции внешнеполитического процесса в Японии.

Таким образом, авторам удалось в учебном пособии достигнуть понимания того, на какие формальные и неформальные соображения опираются те или иные государства, принимая внешнеполитические решения.

Текст пособия не свободен и от определенных недостатков. Проводя глубокий анализ внешнеполитических процессов на постсоветском пространстве, авторы дают только очень сжатую характеристику процессов, происходящих в таких новых независимых государствах, как страны Балтии, ныне входящие в ЕС и НАТО. Это не вполне оправданно, так как эти государства не только являются частью постсоветского пространства, но и, кроме того, играют активную роль во внешнеполитическом процессе в Европе. Анализ опыта стран Балтии был бы тем более полезен для учащихся, что в рамках постсоветского пространства он является уникальным.

К числу удивляющих читателя особенностей учебного пособия следует, пожалуй, отнести и то, что авторы не проводят анализа внешнеполитического процесса в России. И так как работа рассчитана на российскую аудиторию, целесообразно было бы дать характеристику складывающихся в России процессов и механизмов, какими бы противоречивыми и сложными они ни были. Это позволило бы учащимся лучше понять тенденции развития внешнеполитического процесса в России и в мировом масштабе, а также составить полноценную картину внешнеполитического дискурса.

В целом учебное пособие Т.А. Алексеевой и А.А. Казанцева отличается логичностью повествования и проработкой неформальных аспектов влияния на внешнеполитические процессы в различных политиях. Пожалуй, впервые в российском учебно-аналитическом комплексе материалов по международным отношениям и мировой политике для студентов вузов столь пристальное внимание было уделено синтезу формального и неформального знания. Данное исследование предстает в виде объемной, трехмерной модели, где несистемные характеристики играют такую же важную роль, как и системные аспекты.

Избранный авторами подход к проблематике позволяет обучающимся яснее увидеть картину взаимодействия различных акторов внешнеполитического процесса, а также проследить тенденции, выявить закономерности поведения тех или иных участников, лучше понять причинноследственные связи их действий. Это выводит обучающихся на более высокий уровень политического анализа, формирует более глубокую степень их «политической ориентированности» во внешнеполитических процессах.

Nebolsina M.A. A New Vision of Foreign Policy Discourse in Academic and Analytical Literature. 